\title{
The complete mitochondrial genome of Pyxicephalus adspersus: high gene rearrangement and phylogenetics of one of the world's largest frogs
}

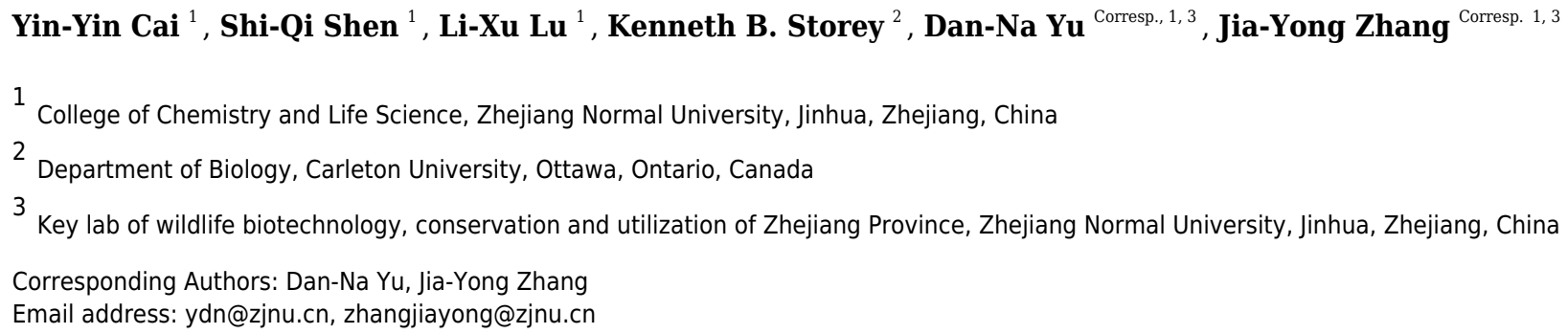

The family Pyxicephalidae including two subfamilies (Cacosterninae and Pyxicephalinae) is an ecologically important group of frogs distributed in sub-Saharan Africa. However, its phylogenetic position among the Anura has remained uncertain. The present study determined the complete mitochondrial genome sequence of Pyxicephalus adspersus, the first representative mitochondrial genome from the Pyxicephalinae, and reconstructed the phylogenetic relationships within Ranoidae using 10 mitochondrial protein-coding genes of 59 frog species. The $P$. adspersus mitochondrial genome showed major gene rearrangement and an exceptionally long length that is not shared with other Ranoidae species. The genome is $24,317 \mathrm{bp}$ in length, and contains 15 protein-coding genes (including extra COX3 and Cyt $b$ genes), four rRNA genes (including extra 12S rRNA and $16 S$ rRNA genes), 29 tRNA genes (including extra $t R N A^{\text {Leu (UAG) }}, t R N A^{\text {Leu (UUR) }}, t R N A^{\text {Thr }}, t R N A^{\text {Pro }}$, $t R N A^{\text {Phe }}, t R N A^{V a l}, t R N A^{G l n}$ genes) and two control regions (CRs). The Dimer-Mitogenome and TDRL models were used to explain these gene arrangements. Finally, both $\mathrm{BI}$ and $\mathrm{ML}$ analyses supported the conclusion that Pyxicephalidae was monophyletic and that Pyxicephalidae was the sister clade of (Petropedetidae + Ptychadenidae). 
1 The complete mitochondrial genome of Pyxicephalus adspersus: high

2 gene rearrangement and phylogenetics of one of the world's largest

3 frogs

4

5 Yin-Yin Cai ${ }^{1}$, Shi-Qi Shen ${ }^{1}$, Li-Xu Lu ${ }^{1}$, Kenneth B. Storey ${ }^{2}$, Dan-Na Yu ${ }^{1,3 *}$, Jia-Yong Zhang ${ }^{1,3^{*}}$

$6 \quad{ }^{I}$ College of Chemistry and Life Science, Zhejiang Normal University, Jinhua, 321004, Zhejiang

7 Province, China

$8 \quad{ }^{2}$ Key lab of wildlife biotechnology, conservation and utilization of Zhejiang Province, Zhejiang

9 Normal University, Jinhua, 321004, Zhejiang Province, China

$10{ }^{3}$ Department of Biology, Carleton University, Ottawa, Ontario, K1S5B6, Canada

11

12 *Corresponding author: DN Yu: ydn@zjnu.cn

13 JY Zhang: zhang3599533@163.com or zhangjiayong@zjnu.cn

16 Other authors:

17 YY Cai: caiyinyin122@163.com

18 SQ Shen: shenshiqi0824@zjnu.edu.cn

19 LX Lu: lulixu@zjnu.edu.cn

KB Storey: kenneth.storey@carleton.ca 
22 Abstract

23 The family Pyxicephalidae including two subfamilies (Cacosterninae and Pyxicephalinae) is an 24 ecologically important group of frogs distributed in sub-Saharan Africa. However, its 25 phylogenetic position among the Anura has remained uncertain. The present study determined 26 the complete mitochondrial genome sequence of Pyxicephalus adspersus, the first representative

27 mitochondrial genome from the Pyxicephalinae, and reconstructed the phylogenetic relationships 28 within Ranoidae using 10 mitochondrial protein-coding genes of 59 frog species. The $P$. 29 adspersus mitochondrial genome showed major gene rearrangement and an exceptionally long 30 length that is not shared with other Ranoidae species. The genome is $24,317 \mathrm{bp}$ in length, and contains 15 protein-coding genes (including extra $C O X 3$ and $C y t b$ genes), four rRNA genes

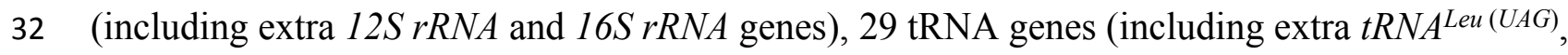
$33 t R N A^{\text {Leu (UUR) }}, t R N A^{T h r}, t R N A^{\text {Pro }}, t R N A^{P h e}, t R N A^{V a l}, t R N A^{G l n}$ genes) and two control regions (CRs).

34 The Dimer-Mitogenome and TDRL models were used to explain these gene arrangements.

35 Finally, both BI and ML analyses supported the conclusion that Pyxicephalidae was 36 monophyletic and that Pyxicephalidae was the sister clade of (Petropedetidae + Ptychadenidae).

\section{$37 \quad$ Keywords}

Pyxicephalidae, mitogenome, gene rearrangement, phylogenetic relationship 


\section{Background}

Anuran mitochondrial (mt) genomes are closed double-stranded DNA molecules with the lengths varying from 15-23 kb (Kakehashi et al., 2013; Zhang et al., 2018a) and typically encode 37 genes: two ribosomal RNAs (12S and 16S rRNAs), 22 transfer RNAs (tRNAs), 13 protein-coding genes (PCGs), and the control region (CR) or D-loop region (Boore, 1999; Boore, 2000). The $\mathrm{mt}$ genome has several valuable characteristics that have led to its wide use as a research tool including limited recombination, maternal inheritance, rapid evolutionary rate, small size and relatively conserved gene arrangement (Avise, 1994). Complete or partial mt genomes have been extensively used to test evolutionary hypotheses, to study population biogeography and phylogenetic relationships, and to distinguish cryptic species (Boore, 1999; Yu et al., 2015; Zhang et al., 2008).

To date, there are 7,977 known species of Anura (Frost, 2019) on Earth, the vast majority of which have not had their mt genomes sequenced and studied. According to Machado et al. (Jacob Machado et al., 2018) and Zhang et al. (2018a), there are partial mt genomes for over one hundred species representing 35 families (72 genera) and complete mt genomes for over two hundred species representing 27 families (76 genera) listed in GenBank. Although nonneobatrachian frogs show conservation of the typical mt gene organization, ranoid frogs belonging to the neobatrachia show a variety of gene rearrangements in their $\mathrm{mt}$ genomes (Kurabayashi \& Sumida, 2013; Zhang et al., 2013). Hence, by increasing the number of sequenced frog $\mathrm{mt}$ genomes, we can gain valuable information about mt genome arrangements and improve our understanding of $\mathrm{mt}$ genomic phylogenetics and evolution, population genetics (Cai et al., 2018; Cheng et al., 2018; Lin et al., 2014; Ni et al., 2015; Ye et al., 2016) and mt genome expression (Zhang et al., 2019).

Some gene rearrangements in the $\mathrm{mt}$ genome have been reported in neobatrachians. For example, some species show a rearrangement of the ND5 gene (eg. Alam et al., 2010; Anoop et al., 2017; Kumar et al., 2017; Li et al., 2014a; Li et al., 2016a; Sano et al., 2004; Sano et al., 2005). A gene rearrangement of ND6 gene has also been reported in several species (Zhang et al., 
68

69

70

71

2018a; Irisarri et al., 2010; Carr et al., 2015; Kakehashi et al., 2013). Two $t R N A^{\text {Met }}$ genes have also been found in many species of Ceratobatrachidae, Dicroglossidae, Mantoidae, and Megophryidae (eg. Jiang et al., 2018; Kiran et al., 2017; Kurabayashi et al., 2008; Li et al., 2018a; Li et al., 2018b; Liang et al., 2016 ). Mantella madagascariensis (Kurabayashi et al., 2006), Rana kunyuensis (Li et al., 2016a), and Rhacophorus schlegelii (Sano et al., 2005) possess duplicated control regions. By contrast, the $t R N A^{T h r}$ gene was lost in Nanorana taihangnica (Chen et al., 2015) and the ATP8 and ND5 genes were lost in Polypedates megacephalus (Zhang et al., 2005).

The phylogenetic relationship of Pyxicephalidae was hotly disputed. Pyxicephalidae contains two subfamilies (Cacosterninae and Pyxicephalinae) with a total of 12 genera and 84 recognized species according to molecular and morphological data (Frost et al., 2006). Using mtDNA and morphological data, van der Meijden suggested that Pyxicephalinae, which is composed solely of Aubria and Pyxicephalus (Frost et al., 2006), was imbedded within the Discroglossine (van der Meijden et al., 2005). By contrast, Wiens et al. (2009) considered Pyxicephalinae as one subfamily of Ranidae. Frost et al. (2006) and Roelants et al. (2007) recovered the monophyly of Pyxicephalidae and van der Meijden et al. (2011) and Pyron and Wiens (2011) treated Pyxicephalidae as a valid family. Zhang et al. (2013) supported Pyxicephalidae as a sister clade to Petropedetidae. Bittencourt-Silva et al. (2016) discussed the phylogenetic relationship of the genera in Pyxicephalidae and concluded that Aubria and Pyxicephalus, belonging to Pyxicephalinae, were the basal clade of Pyxicephalidae. Hence, research on the phylogenetic relationships of Pyxicephalus could reveal the monophyly of Pyxicephalidae.

The African giant bullfrog (Pyxicephalus adspersus) belongs to the subfamily Pyxicephalinae of the family Pyxicephalidae. It is an explosive-breeding anuran that inhabits arid to subtropical grasslands and savanna across most of southern Africa (Channing, 2001; Minter et al., 2004). It is one of the world's largest amphibians, with males (unusually larger than females) reaching a length of $225 \mathrm{~mm}$ (Wager, 1965) and weights of 1.4 to $2.0 \mathrm{~kg}$ (Channing et al., 1994; Loveridge, 1950). Liu et al. (2013) found Scapharca broughtonii (Mollusca: Bivalvia), which is an enlarged 
95

96

97

species compared to other species of Scapharca, had largest mitochondrial genomes among the genus Scapharca (Liu et al., 2013). A species with a giant size within an animal group may be associated with a larger mitogenome (Alam et al., 2010; Yu et al., 2012b; Yu et al., 2015; Zhang et al., 2018a; ).However, no studies in P. adspersus has examined the potential involvement of $\mathrm{mt}$ genome evolution. So we wondered whether this giant bullfrog had novel features of its $\mathrm{mt}$ genome. In the present study, we sequenced the mt genome of $P$. adspersus, the first representative mt genome of the Pyxicephalinae, to determine if mitochondrial gene rearrangement occurred and to study the phylogenetic relationships of Pyxicephalidae.

\section{Materials and methods}

\subsection{Animal treatments}

Pyxicephalus adspersus are not protected by provisions in the laws of the People's Republic of China on the protection of wildlife. Two samples of Pyxicephalus adspersus were purchased from a pet market and bred in the laboratory of JY Zhang at the College of Life Science, Zhejiang Normal University. Sample acquisition was reviewed, approved and carried out in accordance with the relevant guidelines of the Committee of Animal Research Ethics of Zhejiang Normal University.

\subsection{DNA extraction, PCR and sequencing}

Total DNA was extracted from the clipped toe of one specimen using a DNeasy Tissue Kit (Qiagen, Germany). We amplified thirteen overlapping gene fragments by normal polymerase chain reaction (PCR) and long-and-accurate (LA) PCR methods slightly modified from Yu et al. (2015) and Zhang et al. (2013). However, these methods failed to find some mitochondrial genes including $N D 3, N D 5$, and $t R N A^{I l e}, t R N A^{C y s}, t R N A^{L y s}$, and $t R N A^{A r g}$. We subsequently designed one pair of primers to sequence the ND5 gene (ND5-J: ATRGARGGNCCNACACCWGT; ND5-N: CCCATNTTWCGRATRTCCTGGTC) based to the known mitochondrial gene sequences of 53 Ranidae species from GenBank. After we obtained the ND5 gene fragment, we then designed two pairs of specific primers for ND6 (ND65-J: ACAAGAGCAGAACAATAAGC, ND65-N: 
122

123

124

125

126

127

128

129

130

131

132

133

134

135

136

137

138

139

140

141

142

TAGAGTGGAGTAAGGCAGAA and ND56-J: ATACAACCGAATTGGAGACA, ND56-N:

GGTAAATCAGTGGGTAGGTAT) to sequence the fragment ranging from ND6 to ND5 genes and the fragment ranging from ND5 to ND6 genes, respectively. Surprisingly, when the two fragments from ND6 to ND5 and ND5 to ND6 were amplified their sizes proved to be nearly $8000 \mathrm{bp}$ and $15000 \mathrm{bp}$, respectively. All PCR was performed using a programmable Thermal Cycler (Veriti PCR Thermal Cycler, Applied Biosystems, CA, USA) or a MyCycler Thermal Cycler (Bio-Rad, CA, USA). TaKaRa LA-Taq kits and TaKaRa Ex-Taq (Takara Biomedical, Dalian, China) were used for LA-PCR and normal PCR reactions, respectively. PCR products were electrophoresed on $1 \%$ or $2 \%$ agarose gels and sequences were obtained using an ABI 3730 automated DNA sequencer (Applied Biosystems, CA, USA) using the primers walking method for both strands.

\subsection{Sequence assembly, annotation and analysis}

Sequences were checked and assembled using SeqMan (Lasergene version 5.0) (Burland, 2000). All mt genes were determined by Mitos WebServer (Bernt et al., 2013). The locations of the 15 protein coding genes and four rRNA genes were further identified by comparison with the homologous sequences of closely related anurans downloaded from GenBank. All tRNA genes were further determined using tRNA-scan SE 2.0 (Chan \& Lowe, 2010) or determined by comparison with the homologous sequences of other anurans. The mt genome was deposited in GenBank with accession number MK460224. The mt genome map of $P$. adspersus was formed using GenomeVx (Conant \& Wolfe, 2008) (http://wolfe.ucd.ie/GenomeVx/). The A+T content, codon usage and relative synonymous codon usage (RSCU) of protein-coding genes were calculated by Mega 7.0 (Stecher et al., 2016). Composition skewness was calculated according to the following formulae: AT-skew $=(\mathrm{A}-\mathrm{T}) /(\mathrm{A}+\mathrm{T}) ; \mathrm{GC}$-skew $=(\mathrm{G}-\mathrm{C}) /(\mathrm{G}+\mathrm{C})($ Perna \& Kocher, 1995).

\subsection{Molecular phylogenetic analysis}

The phylogenetic analyses was performed using the combined nucleotide datasets by the 
150

151

152

153

154

155

156

157

158

159

160

161

162

163

164

165

166

167

168

169

170

171

172

173

174

175

176

Bayesian inference (BI) and maximum likelihood (ML) methods. BI and ML analyses were performed with 59 anuran $\mathrm{mt}$ genomes including $P$. adspersus. In total this included 55 species as the ingroup from Ranidae, Dicroglossidae, Rhacophoridae, Mantellidae, Pyxicephalidae, Petropedetidae, Ptychadenidae, Ceratobatrachidae and Phrynobatrachidae (Alam et al., 2010; Chen et al., 2011; Hofman et al., 2012; Huang et al., 2016a; Huang et al., 2016b; Jiang et al., 2017; Kakehashi et al., 2013; Kurabayashi et al., 2006; Kurabayashi et al., 2010; Li et al., 2016b; Li et al., 2014b; Lin et al., 2014; Liu et al., 2017a; Liu et al., 2017b; Liu et al., 2005; Ni et al., 2015; Ren et al., 2009; Sano et al., 2004; Sano et al., 2005; Xia et al., 2014; Yan et al., 2016; Yang et al., 2018; Yu et al., 2015; Yu et al., 2012a; Yu et al., 2012b; Zhang et al., 2016; Zhang et al., 2018a; Zhang et al., 2009; Zhang et al., 2013; Zhang et al., 2005; Zhao et al., 2018; Zhou et al., 2009) and four species as outgroups from Microhylidae (Chen et al., 2016; Wang et al., 2018; Zhao et al., 2018). We used the nucleotide data to assess BI and ML topology to discuss the phylogenetic position of Pyxicephalus. Although extra COX3 and Cyt $b$ genes were found in Pyxicephalus adspersus (see the result in the following context), the extra copies of $C O X 3$ and $C y t b$ genes were identical to the other $C O X 3$ and $C y t b$ genes (100\% similarity). Therefore, in phylogenetic analyses, only one set genes of $C O X 3$ and $C y t b$ was used. In addition, due to some mitochondrial protein-coding genes missing in some species (ND5), lacking good information (ATP8) and the heterogeneous base composition and poor phylogenetic performance (ND6) (Zhang et al., 2018a), ten PCGs genes were used in this study and separately aligned in Mega 7.0 (Stecher et al., 2016). All genes were split jointed, clustered, Gblocked and concatenated using PhyloSuite v1.1.13 (Zhang et al., 2018b). An alignment of the $10 \mathrm{mt}$ PCGs dataset consisting of 7244 nucleotides sites was concatenated. To obtain the substitution model of the $10 \mathrm{mt}$ PCGs dataset, data partitioning schemes were compared according to the Bayesian Information Criterion (BIC) using the program PartitionFinder v1.0 (Lanfear et al., 2012). We set the 10 PCGs as 30 partitions in the $10 \mathrm{mt}$ PCGs dataset according to the codon positions (the first, second and third position) and gene numbers (ten PCGs). The best substitution model of the 30 partitions of the $10 \mathrm{mt}$ PCGs dataset is shown in Table 1. Next, a GTRGAMMAI model in the 
177

178

179

180

181

182

183

184

185

186

187

188

189

190

191

192

193

194

195

196

197

198

199

200

201

202

203

RaxML program (Stamatakis, 2006) for the $10 \mathrm{mt}$ PCGs dataset with 30 partitions was used for ML analysis and the GTR + I + G model in the MrBayes3.1.2 (Huelsenbeck \& Ronquist, 2001) was used for Bayesian analysis. During BI analysis, the following settings were applied: number of Markov chain Monte Carlo $(\mathrm{MCMC})$ generations = 10 million; sampling frequency = 1000; burn-in $=1000$. The burn-in size was determined by checking convergences of -log likelihood $(-\ln \mathrm{L})$. Bayesian runs achieved sufficient convergence when the average standard deviation of split frequencies was below 0.01 .

\section{Results and discussion}

\section{Mitogenome characteristics of $P$. adspersus}

The length of the $P$. adspersus $\mathrm{mt}$ genome was $24,317 \mathrm{bp}$ and the $\mathrm{mt}$ genome encoded 15 protein-coding genes (including extra $C O X 3$ and $C y t b$ genes), four rRNA genes (2 each of $12 S$ $r R N A$ and $16 S r R N A$ genes), 29 tRNA genes (including extra $t R N A^{\operatorname{Leu}(U A G)}, t R N A^{T h r}, t R N A^{\text {Pro }}$, $t R N A^{P h e}, t R N A^{\text {Leu }(U U R)}, t R N A^{V a l}$, and $t R N A^{G l n}$ genes) and two control regions (CRs) (including one extra CR) (Fig. 1 and Table 2). All PCGs excluding the ND6 gene and four rRNA genes as well as all tRNA genes excluding $t R N A^{A l a}, t R N A^{A s n}, t R N A^{C y s}, t R N A^{G l n}, t R N A^{G l u}, t R N A^{P r o}, t R N A^{S e r}$, $t R N A^{T y r}$ genes were encoded on the major strand. The length of the $P$. adspersus mitogenome was the largest size among all known anuran mitogenomes.

A total $22 \mathrm{bp}$ intergenic overlap inferring to ten genes was found in the mt genome of $P$. adspersus. The total non-coding regions (NCRs) in the mitogenome was $1376 \mathrm{bp}$, composed of 13 larger non-coding regions (NCRs) ranging from 22-324 bp and many smaller regions (1-10 bp) (Fig. 1 and Table 2). NCR13 between ND5 and Glu was 324 bp and showed 92.6\% similarity with the ND6 gene. NCR11 between $C O X 3$ and ND3 genes showed $73.9 \%$ similarity with the $t R N A^{G l y}$ gene and NCR7 between $t R N A^{\text {Leu }}$ and $t R N A^{\text {Ile }}$ genes was $100 \%$ similar to the 5 ' segment of the NDl gene. The other spacer regions showed $48.7 \%-67.3 \%$ similarity with corresponding gene clusters (Table 3 ).

Thirteen NCRs also had high homology compared to corresponding deleted genes (Table 3). The 
204

205

206

207

208

209

210

211

212

213

214

215

216

217

218

219

220

221

222

223

224

225

226

227

228

229

230

$t R N A^{\text {Ile }}$ gene moved from the typical IQM tRNA cluster to a position between the 22 bp NCR7 and a $219 \mathrm{bp} \mathrm{NCR8} \mathrm{and} \mathrm{the} \mathrm{corresponding} \mathrm{location} \mathrm{of} \mathrm{the} t R N A^{\text {Ile }}$ gene between the ND1 and $t R N A^{G l n}$ genes was replaced by a 60 bp NCR1 (50\% similarity with Ile). The $O_{L^{-}} t R N A^{C y s}$ genes also moved from the $W A N O_{L} C Y$ tRNA cluster to a position between a $219 \mathrm{bp} \mathrm{NCR} 8$ and the $t R N A^{A s p}$ gene, whereas a $39 \mathrm{bp}$ NCR2 was formed in the position between $t R N A^{A s n}$ and $t R N A^{T y r}$ genes. The $t R N A^{A s p}$ gene moved from the typical position between $t R N A^{S e r}$ and $C O X 2$ genes to a location between the $t R N A^{C y s}$ gene and a 151 bp NCR9 and the former position was replaced by a 59 bp NCR3. The $t R N A^{L y s}$ gene moved from the typical position between $C O X 2$ and $A T P 8$ genes to a location between a 151 bp NCR9 and a 54 bp NCR10 and the former position was replaced by a $61 \mathrm{bp}$ NCR3. The ND3-tRNA $A^{A r g}$ genes moved from the typical position between $t R N A^{G l y}$ and $N D 4 L$ genes to a location between a 65 NCR11 and ND5 and the former position was replaced by a $150 \mathrm{bp}$ NCR5. The ND5 gene moved from the typical position between $t R N A^{\text {Ser }}$ and ND6 genes to a location between the $98 \mathrm{bp}$ NCR12 and the $324 \mathrm{bp} \mathrm{NCR} 13$ and the former position was replaced by a 143 bp NCR6.

There were 15 PCGs in the mt genome of $P$. adspersus, including two COX1 and two Cyt $b$ genes; in both cases the two copies of each gene were identical. Protein-coding genes started with ATN codons except for COX1, which used GTG. Most PCGs ended with a complete TAN codon or with an incomplete T or TA except for ND5 and ND6 that showed AGG as the termination codon. Relative synonymous codon usage (RSCU) and codon counts for the mt genome of $P$. adspersus are shown in Fig. 2. It was evident that the most frequently used codon was CGA, followed by GCC, CAA and CCC. Leu (UUR), Ile and Phe as the most frequently used amino acids were also found.

The genome composition (A: 29.5\%, C: 27.8\%, G: 14.5\%, T: 28.2\%) showed an A+T bias, which accounted for $57.7 \%$ of the bases, and exhibited a negative GC-skew (-0.31) and a positive AT-skew (0.02) (Table 4). The highest A+T content (65.5\%) was found in the control region, whereas the lowest $\mathrm{A}+\mathrm{T}$ content (56.5\%) was found in the PCGs region.

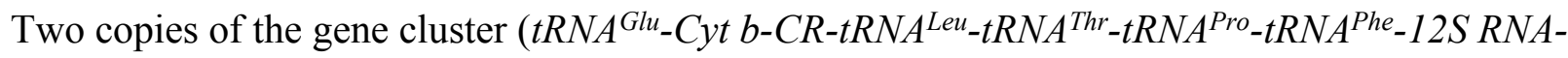


231

232

233

234

235

236

237

238

239

240

241

242

243

244

245

246

247

248

249

250

251

252

253

254

255

256

257

$t R N A^{V a l}$-16S RNA-tRNA $A^{\text {Leu }}$ ) occurred, one between ND6 and $t R N A^{\text {Ile }}$ genes and the other between ND5 and ND1 genes. Remarkably, the nearly identical nucleotide sequences $(99.99 \%$ similarity with only one $\mathrm{G}$ base extra inserted into $t R N A^{G l u}$ of the 5454 alignment sites) were found in the two copies of these gene clusters The extra $C O X 3$ gene was located between $t R N A^{L y s}$ and $N D 3$ genes. The $t R N A^{I l e}$ gene moved from the typical neobatrachian IQM tRNA cluster to a location between the $t R N A^{L e u}$ and $t R N A^{C y s}$ genes whereas the $t R N A^{C y s}$ gene moved from the typical neobatrachian $W A N C Y$ tRNA cluster to a location between the $t R N A^{I l e}$ and $t R N A^{L y s}$ genes. The $t R N A^{L y s}$ gene moved from the typical neobatrachian position between $C O X 2$ and ATP 8 genes to a location between $t R N A^{C y s}$ and the extra $C O X 3$ gene. The $N D 3-t R N A^{A r g}$ genes moved from the position between $t R N A^{G l y}$ and $N D 4 L$ genes to a location between the COX3 and ND5 genes. The ND5 gene moved from the typical neobatrachian position between $t R N A^{S e r}$ and $N D 6$ genes to a location between the $t R N A^{A r g}$ and $t R N A^{G l u}$ genes.

The mt genome of $P$. adspersus contained two copies of the $16 S r R N A$ and $12 S r R N A$ genes and each copy was identical to its original. The two copies of the 16S rRNA gene with a length of $1,578 \mathrm{bp}$ were located between two copies of $t R N A^{\text {Leu }}$ and $t R N A^{\text {Val }}$ genes, respectively, whereas the two copies of the $12 S r R N A$ gene with a length of $932 \mathrm{bp}$ were located between two copies of $t R N A^{P h e}$ and $t R N A^{V a l}$ genes, respectively (Fig 1). We found that the AT-skew was slightly positive whereas the GC-skew was strongly negative in the skew of the rRNA genes (Table 4), which showed that the contents of $\mathrm{A}$ and $\mathrm{C}$ were higher than those of $\mathrm{T}$ and $\mathrm{G}$, respectively. The mt genome of $P$. adspersus contained 29 tRNA genes: two copies of $L T P F$ gene clusters, two copies of $t R N A^{L e u}$, two copies of $t R N A^{V a l}$, two copies of $t R N A^{G l n}$; the tRNA sequences of each copy were identical. However, $t R N A^{I l e}, t R N A^{C y s}$ and $t R N A^{L y s}$ genes were transferred from the original regions. The existence of two copies of a tRNA gene is uncommon. The size of the tRNAs was $2,021 \mathrm{bp}$ with an average A+T content of 56.6\%. Among the 29 tRNAs, most tRNA genes excluding $t R N A^{\operatorname{Ser}(\mathrm{AGN})}$ have the common cloverleaf secondary structure. The mt genome of $P$. adspersus also contained two copies of the control region and each $C R$ copy had an identical length of $1306 \mathrm{bp}$ and was located between two copies of the Cyt $b$ and $t R N A^{\text {Leu }}$ genes. 


\section{Possible gene rearrangement mechanisms of $\boldsymbol{P}$. adspersus mtDNA}

260

261

262

263

264

265

266

267

268

269

270

271

272

273

274

275

276

277

278

279

280

281

282

283

284

285

In $P$. adspersus, two copies of the $t R N A^{G l u_{-}} C y t$ b-CR-tRNA $A^{\text {Leu }}-t R N A^{T h r_{-}} t R N A^{P r o}-t R N A^{P h e_{-}} 12 S$

$R N A-t R N A^{V a l}$-16S RNA-tRNA $A^{\text {Leu }}$ gene cluster, two copies of the COX3 gene, and the translocation of $t R N A^{I l e}, t R N A^{C y s}, t R N A^{A s p}, t R N A^{L y s}, t R N A^{A r g}, N D 3$ and $N D 5$ genes from their typical positions were found. Comparing the mt gene rearrangements in all sequenced mitochondrial genomes of frogs, we did not find any other species where similar gene rearrangements existed. The Tandem Duplication and Random Loss model (TDRL) (Arndt \& Smith, 1998) can be used to explain the gene rearrangement in $P$. adspersus. The rearrangement mechanism of hypothesized intermediate steps is as follows (Fig. 3). Firstly, the two mitochondrial genomes were linked by the head-to-tail method and the inferred "dimer-mitogenome" intermediate of the P. adspersus mtDNA could be formed from two entire mitogenomes. Secondly, some copies of duplicated genes were randomly deleted completely or partially from the two mt monomers. Thirdly, some duplicated genes lost their functions or became noncoding regions. This then formed the gene arrangement of $P$. adspersus. Hence, the Dimer-Mitogenome and the TDRL model (Arndt \& Smith, 1998) may be the most appropriate to explain the gene arrangements in P. adspersus.

\section{Phylogenetic analysis}

We illustrated nodal supports from ML and BI analyses together using Bayesian topology (Fig. 4) because the combined data set consisting of 10 protein coding sequences resulted in identical topology for phylogenetic relationships. Both ML and BI analyses showed high branch support values. Dicroglossidae is a sister clade of Ranidae. The clade of Mantellidae and Rhacophoridae is a sister clade of Dicroglossidae and Ranidae. Petropedetidae is a sister clade of Ptychadenidae and then Pyxicephalidae is a sister clade of (Petropedetidae + Ptychadenidae). The clade of (Pyxicephalidae $+($ Petropedetidae + Ptychadenidae $))$ is a sister clade of (Dicroglossidae + Ranidae $)+($ Mantellidae + Rhacophoridae). Ceratobatrachidae is a sister clade of Phrynobatrachidae. The clade of Ceratobatrachidae and Phrynobatrachidae is a sister clade of $(($ Pyxicephalidae $+($ Petropedetidae + Ptychadenidae $))+($ Dicroglossidae + Ranidae $)+$ 
286 (Mantellidae + Rhacophoridae). Pyxicephalus adspersus is a sister clade of Tomopterna cryptotis.

287 The monophyly of Dicroglossidae, Ranidae, Mantellidae, Rhacophoridae, Pyxicephalidae, and

288 Ceratobatrachidae was well supported.

289 The monophyly of Pyxicephalidae is supported for Pyxicephalus adspersus (Pyxicephalinae) as a 290 sister clade of Tomopterna cryptotis (Cacosterninae). Pyxicephalidae is a valid family in this 291 study as was also supported by the results of Frost et al. (2006), Roelants et al. (2007), and Pyron 292 and Wiens (2011). Although Scott and van der Meijden supported Pyxicephalinae as imbedded 293 within the Discroglossine (Scott, 2005; van der Meijden et al., 2005), Pyxicephalus adspersus 294 (Pyxicephalidae) is not clustered into Dicroglossidae or Ranidae, whereas Dicroglossidae is a 295 sister clade of Ranidae, which is supported by Zhang et al. (2018a). Zhang et al. (2013) 296 supported Pyxicephalidae as a sister clade to Petropedetidae, our results supported 297 Pyxicephalidae as monophyletic and Pyxicephalidae was a sister clade of Petropedetidae and 298 Ptychadenidae.

299 4. Conclusions

300 We successfully determined the complete mitogenome of Pyxicephalus adspersus. The length of 301 the P. adspersus mitogenome (24,317 bp) was the largest size among all known anurans 302 mitogenomes. We found two copies of the $t R N A^{G l u_{-} C y t} b_{-} C R-t R N A^{L^{e u}}-t R N A^{T h r_{-}} t R N A^{P r o}-t R N A^{P h e_{-}}$ $30312 S R N A-t R N A^{V a l}-16 S R N A-t R N A^{\text {Leu }}$ gene clusters, two copies of COX3 genes, and the 304 translocation of $t R N A^{I l e}, t R N A^{C y s}, t R N A^{A s p}, t R N A^{L y s}, t R N A^{A r g}, N D 3$ and $N D 5$ genes from their 305 typical positions. The Dimer-Mitogenome and TDRL models may be the most appropriate to 306 explain the gene arrangements in P. adspersus. In this study, both BI and ML analyses supported 307 the conclusion that Pyxicephalidae was monophyletic and Pyxicephalidae was the sister clade of 308 (Petropedetidae + Ptychadenidae). 


\section{References}

Alam MS, Kurabayashi A, Hayashi Y, Sano N, Khan MMR, Fujii T, and Sumida M. 2010. Complete mitochondrial genomes and novel gene rearrangements in two dicroglossid frogs, Hoplobatrachus tigerinus and Euphlyctis hexadactylus, from Bangladesh. Genes and Genetic Systems 85(3):219-232. DOI 10.1266/ggs.85.219.

Anoop VS, Kumar KS, Sivakumar KC, Reghunathan D, Manoj P, Deuti K, and George S. 2017. The complete mitochondrial genome of Euphlyctis karaavali (Amphibia: Anura) with a note on its range expansion. Conservation Genetics Resources 9(3):427-430. DOI 10.1007/s12686-017-0703-7.

Arndt A, and Smith M. 1998. Mitochondrial gene rearrangement in the sea cucumber genus Cucumaria. Molecular Biology and Evolution 15(8):1009-1016. DOI 10.1093/oxfordjournals.molbev.a025999.

Avise JC. 1994. Molecular markers, natural history and evolution. New York: Champman and Hall.

Bernt M, Donath A, Jühling F, Externbrink F, Florentz C, Fritzsch G, Pütz J, Middendorf M, and Stadler PF. 2013. MITOS: Improved de novo metazoan mitochondrial genome annotation. Molecular Phylogenetics and Evolution 69(2):313-319. DOI 10.1016/j.ympev.2012.08.023.

Bittencourt-Silva GB, Conradie W, Siu-Ting K, Tolley KA, Channing A, Cunningham M, Farooq HM, Menegon M, and Loader SP. 2016. The phylogenetic position and diversity of the enigmatic mongrel frog Nothophryne Poynton, 1963 (Amphibia, Anura). Molecular Phylogenetics and Evolution 99:89-102. DOI 10.1016/j.ympev.2016.03.021.

Boore JL. 1999. Animal mitochondrial genomes. Nucleic Acids Research 27(8):1767-1780. DOI 10.1093/nar/27.8.1767.

Boore JL. 2000. The duplication/random loss model for gene rearrangement exemplified by mitochondrial genomes of deuterostome animals. In: Sankoff D, and Nadeau JH, eds. Comparative genomics: empirical and analytical approaches to gene order dynamics, map alignment and the evolution of gene families. Dordrecht: Kluwer Academic Publishers, 133-216.

Burland TG. 2000. DNASTAR's Lasergene sequence analysis software. In: Misener S, Krawetz SA, eds. Bioinformatics Methods and Protocols. Methods in Molecular Biology. Totowa: Humana Press, 71-91.

Cai YT, Ma L, Xu CJ, Li P, Zhang JY, Storey KB, and Yu DN. 2018. The complete mitochondrial genome of the hybrid of Hoplobatrachus chinensis $(+9) \times$ H. rugulosus $\left({ }^{\Uparrow}\right)$ and its phylogeny. Mitochondrial DNA Part B 3(1):344-345. DOI 10.1080/23802359.2018.1450661.

Carr LM, McLenachan PA, Waddell PJ, Gemmell NJ, and Penny D. 2015. Analyses of the mitochondrial genome of Leiopelma hochstetteri argues against the full drowning of New Zealand. Journal of biogeography 42(6):1066-1076. DOI 10.1111/jbi.12482.

Chan PP, and Lowe TM. 2016. tRNAscan-SE On-line: integrating search and context for analysis of transfer RNA genes. Nucleic Acids Research 44(W1):W54-W57. DOI 10.1093/nar/gkw413.

Channing A. 2001. Amphibians of Central and Southern Africa. Protea Book House, Pretoria, South Africa.

Channing A, DU Preez L, and Passmore N. 1994. Status, vocalization and breeding biology of two species of African bullfrogs (Ranidae: Pyxicephalus). Journal of Zoology 234(1):141-148. DOI 10.1111/j.14697998.1994.tb06061.x.

Chen G, Wang B, Liu J, Xie F, and Jiang JP. 2011. Complete mitochondrial genome of Nanorana pleskei (Amphibia: Anura: Dicroglossidae) and evolutionary characteristics of the amphibian mitochondrial 
genomes. Current Zoology 57(6):785-805. DOI 10.1093/czoolo/57.6.785.

Chen X, He K, Ding ZL, Li GM, Adeola AC, Murphy R, Wang WZ, and Zhang YP. 2016. An improved de novo pipeline for enrichment of high diversity mitochondrial genomes from Amphibia to high-throughput sequencing. bioRxiv 080689. DOI 10.1101/080689.

Chen Z, Zhai X, Zhang J, and Chen X. 2015. The complete mitochondrial genome of Feirana taihangnica (Anura: Dicroglossidae). Mitochondrial DNA 26(3):485-486. DOI 10.3109/19401736.2014.908362.

Cheng JX, Cai YT, Zheng YJ, Zhang JY, Storey KB, Bao YX, and Yu DN. 2018. The complete mitochondrial genome of Fejervarya kawamurai (Anura: Dicroglossidae) and its phylogeny. Mitochondrial DNA Part B 3(2):551-553. DOI 10.1080/23802359.2018.1467219.

Conant GC, and Wolfe KH. 2008. GenomeVx: simple web-based creation of editable circular chromosome maps. Bioinformatics 24(6):861-862. DOI 10.1093/bioinformatics/btm598.

Frost DR. 2019. Amphibian Species of the World: an Online Reference. Version 6.0 (1 Dec. 2016). American Museum of Natural History, New York, USA.

Frost DR, Grant T, Faivovich J, Bain RH, Haas A, Haddad CFB, De Sa RO, Channing A, Wilkinson M, and Donnellan SC. 2006. The amphibian tree of life. Bulletin of the American Museum of Natural History 2006(297):1-291. DOI 10.1206/0003-0090(2006)297[0001:TATOL]2.0.CO;2.

Hofman S, Pabijan M, Dziewulska-Szwajkowska D, and Szymura JM. 2012. Mitochondrial genome organization and divergence in hybridizing central European waterfrogs of the Pelophylax esculentus complex (Anura, Ranidae). Gene 491(1):71-80. DOI 10.1016/j.gene.2011.08.004.

Huang M, Duan R, Kong X, Wang H, and Zhu H. 2016a. The complete mitochondrial genome of Amolops wuyiensis (Anura: Ranidae). Mitochondrial DNA Part A 27(3):1705-1706. DOI 10.3109/19401736.2014.961131.

Huang M, Lv T, Duan R, Zhang S, and Li H. 2016b. The complete mitochondrial genome of Rhacophorus dennysi (Anura: Rhacophoridae) and phylogenetic analysis. Mitochondrial DNA Part A 27(5):3719-3720. DOI 10.3109/19401736.2015.1079873.

Huelsenbeck JP, and Ronquist F. 2001. MRBAYES: Bayesian inference of phylogenetic trees. Bioinformatics 17(8):754-755. DOI 10.1093/bioinformatics/17.8.754.

Irisarri I, San Mauro D, Green DM, and Zardoya R. 2010. The complete mitochondrial genome of the relict frog Leiopelma archeyi: Insights into the root of the frog Tree of Life. Mitochondrial DNA 21(5):173-182. DOI 10.3109/19401736.2010.513973.

Jacob Machado D, Janies D, Brouwer C, and Grant T. 2018. A new strategy to infer circularity applied to four new complete frog mitogenomes. Ecology and Evolution 8(8):4011-4018. DOI 10.1002/ece3.3918.

Jiang L, Li S, Wang L, Gao X, Wang G, and Wang B. 2018. The complete mitochondrial genome of the toad species Oreolalax jingdongensis (Anura: Megophryidae) and related phylogenetic analyses. Conservation Genetics Resources 10(4):873-876. DOI 10.1007/s12686-017-0885-z.

Jiang L, Zhao L, Liu Y, Leng Z, Zhao L, and Ruan Q. 2017. The complete mitochondrial genome sequence of the Dark-spotted frog Pelophylax nigromaculatus (Amphibia, Anura, Ranidae). Mitochondrial DNA Part A 28(2):236-237. DOI 10.3109/19401736.2015.1115857.

Kakehashi R, Kurabayashi A, Oumi S, Katsuren S, Hoso M, and Sumida M. 2013. Mitochondrial genomes of Japanese Babina frogs (Ranidae, Anura): unique gene arrangements and the phylogenetic positionof genus Babina. Genes and Genetic Systems 88(1):59-67. DOI 10.1266/ggs.88.59. 
391

392

393

394

395

396

397

398

399

400

401

402

403

404

405

406

407

408

409

410

411

412

413

414

415

416

417

418

419

420

421

422

423

424

425

426

427

428

429

430

431

Kiran SK, Anoop VS, Sivakumar KC, Dinesh R, Mano JP, Kaushik D, and Sanil G. 2017. An additional record of Fejervarya manoharani Garg and Biju from the Western Ghats with a description of its complete mitochondrial genome. Zootaxa 4277 (4):491. DOI 10.11646/zootaxa.4277.4.2.

Kumar KS, Sivakumar KC, Reghunathan D, Manoj P, and George S. 2017. The complete mitochondrial genome of Indirana semipalmata (Amphibia: Anura). Conservation Genetics Resources 9(1):83-86. DOI 10.1007/s12686-016-0625-9.

Kurabayashi A, and Sumida M. 2013. Afrobatrachian mitochondrial genomes: genome reorganization, gene rearrangement mechanisms, and evolutionary trends of duplicated and rearranged genes. BMC Genomics 14:633. DOI 10.1186/1471-2164-14-633.

Kurabayashi A, Sumida M, Yonekawa H, Glaw F, Vences M, and Hasegawa M. 2008. Phylogeny, recombination, and mechanisms of stepwise mitochondrial genome reorganization in mantellid frogs from Madagascar. Molecular Biology and Evolution 25(5):874-891. DOI 10.1093/molbev/msn031.

Kurabayashi A, Usuki C, Mikami N, Fujii T, Yonekawa H, Sumida M, and Hasegawa M. 2006. Complete nucleotide sequence of the mitochondrial genome of a Malagasy poison frog Mantella madagascariensis: Evolutionary implications on mitochondrial genomes of higher anuran groups. Molecular Phylogenetics and Evolution 39(1):223-236. DOI 10.1016/j.ympev.2005.11.021.

Kurabayashi A, Yoshikawa N, Sato N, Hayashi Y, Oumi S, Fujii T, and Sumida M. 2010. Complete mitochondrial DNA sequence of the endangered frog Odorrana ishikawae (Family Ranidae) and unexpected diversity of $\mathrm{mt}$ gene arrangements in ranids. Molecular Phylogenetics and Evolution 56(2):543-553. DOI 10.1016/j.ympev.2010.01.022.

Lanfear R, Calcott B, Ho SY, and Guindon S. 2012. PartitionFinder: combined selection of partitioning schemes and substitution models for phylogenetic analyses. Molecular Biology and Evolution 29(6):1695-1701. DOI 10.1093/molbev/mss020.

Li E, Li X, Wu X, Feng G, Zhang M, Shi H, Wang L, and Jiang J. 2014a. Complete nucleotide sequence and gene rearrangement of the mitochondrial genome of Occidozyga martensii. Journal of Genetics 93(3):631-641. DOI 10.1007/s12041-014-0418-4.

Li J, Yin W, Xia R, Lei G, and Fu C. 2016a. Complete mitochondrial genome of a brown frog, Rana kunyuensis (Anura: Ranidae). Mitochondrial DNA Part A 27(1):34-35. DOI 10.3109/19401736.2013.869681.

Li S, Gao X, Jiang J, and Wang B. 2018a. Complete mitogenome of the toad species Oreolalax multipunctatus (Anura: Megophryidae) and phylogenetic analyses of Megophryidae. Conservation Genetics Resources DOI 10.1007/s12686-018-0999-y.

Li S, Gao X, Wei G, Wang B, and Xu N. 2018b. The complete mitochondrial genome of the toad species Oreolalax xiangchengensis (Anura: Megophryidae) and phylogenetic analyses. Mitochondrial DNA Part B 3(2):12981299. DOI 10.1080/23802359.2018.1535842.

Li Y, Wu X, Zhang H, Yan P, Xue H, and Wu X. 2016b. The complete mitochondrial genome of Amolops ricketti (Amphidia, Anura, Ranidae). Mitochondrial DNA Part A 27(1):242-243. DOI 10.3109/19401736.2014.883606.

Li Y, Zhang H, Wu X, Xue H, Yan P, and Wu X. 2014b. A novel mitogenomic rearrangement for Odorrana schmackeri (Anura: Ranidae) and phylogeny of Ranidae inferred from thirteen mitochondrial proteincoding genes. Amphibia-Reptilia 35(3):331-343. DOI 10.1163/15685381-00002958.

Liang XX, Shu GC, Wang B, Jiang JP, Li C, and Xie F. 2016. Complete mitochondrial genome of the Leishan 
432

433

434

435

436

437

438

439

440

441

442

443

444

445

446

447

448

449

450

451

452

453

454

455

456

457

458

459

460

461

462

463

464

465

466

467

468

469

470

471

472

moustache toad, Vibrissaphora leishanensis (Anura: Megophryidae). Mitochondrial DNA Part B 1(1):275276. DOI 10.1080/23802359.2016.1159937.

Lin Y, Tao B, Fang X, Wang T, and Zhang J. 2014. The complete mitochondrial genome of Lithobates catesbeianus (Anura: Ranidae). Mitochondrial DNA 25(6):447-448. DOI 10.3109/19401736.2013.814115.

Liu YG, Kurokawa T, Sekino M, Tanabe T, and .Watanabe K. 2013. Complete mitochondrial DNA sequence of the ark shell Scapharca broughtonii: An ultra-large metazoan mitochondrial genome. Comparative Biochemistry and Physiology Part D: Genomics and Proteomics 8(1):72-81. DOI 10.1016/j.cbd.2012.12.003.

Liu P, Wang H, and Zhao W. 2017a. Sequencing and analysis of the complete mitochondrial genome of Rana amurensis (Anura: Ranidae). Mitochondrial DNA Part B 2(2):424-425. DOI 10.1080/23802359.2017.1357444.

Liu W, Tao J, Wang H, Zhao W, and Liu P. 2017b. Sequencing and analysis of the complete mitochondrial genome of Rugosa emeljanovi (Anura: Ranidae). Mitochondrial DNA Part B 2(2):383-384. DOI 10.1080/23802359.2017.1347841.

Liu ZQ, Wang YQ, and Su B. 2005. The mitochondrial genome organization of the rice frog, Fejervarya limnocharis (Amphibia: Anura): a new gene order in the vertebrate mtDNA. Gene 346(14):145-151. DOI 10.1016/j.gene.2004.10.013.

Loveridge A. 1950. History and habits of the East African bullfrog. Nairobi The East Africa Natural History Society 19:253-275.

Minter LR, M. Burger, J. A. Harrison, H. H. Braack, P. J. Bishop, and . DK. 2004. Atlas and Red Data Book of the Frogs of South Africa, Lesotho and Swaziland. SI/MAB Series \#9. Smithsonian Institute and Avian Demography Unit.

Ni N, Yu D, Storey KB, Zheng R, and Zhang J. 2015. The complete mitochondrial genome of Lithobates sylvaticus (Anura: Ranidae). Mitochondrial DNA 27(4): 2460-2461. DOI 10.3109/19401736.2015.1033697.

Perna N, and Kocher T. 1995. Patterns of nucleotide composition at four fold degenerate sites of animal mitochondrial genomes. Journal of Molecular Evolution 41(3):353-358. DOI 10.1007/BF00186547.

Pyron AR, and Wiens JJ. 2011. A large-scale phylogeny of Amphibia including over 2800 species, and a revised classification of extant frogs, salamanders, and caecilians. Molecular Phylogenetics and Evolution 61(2):543-583. DOI 10.1016/j.ympev.2011.06.012.

Ren Z, Zhu B, Ma E, Wen J, Tu T, Cao Y, Hasegawa M, and Zhong Y. 2009. Complete nucleotide sequence and gene arrangement of the mitochondrial genome of the crab-eating frog Fejervarya cancrivora and evolutionary implications. Gene 441(1-2):148-155. DOI 10.1016/j.gene.2008.09.010.

Roelants K, Gower DJ, Wilkinson M, Loader SP, Biju SD, Guillaume K, Moriau L, and Bossuyt F. 2007. Global patterns of diversification in the history of modern amphibians. Proceedings of the National Academy of Sciences 104(3):887-892. DOI 10.1073/pnas.0608378104.

Sano N, Kurabayashi A, Fujii T, Yonekawa H, and Sumida M. 2004. Complete nucleotide sequence and gene rearrangement of the mitochondrial genome of the bell-ring frog, Buergeria buergeri (family Rhacophoridae). Genes and Genetic Systems 79(3):151-163. DOI 10.1266/ggs.79.151.

Sano N, Kurabayashi A, Fujii T, Yonekawa H, and Sumida M. 2005. Complete nucleotide sequence of the mitochondrial genome of Schlegeli's tree frog Rhacophorus schlegelii (family Rhacophoridae): duplicated control regions and gene rearrangements. Genes and Genetic Systems 80(3):213-224. DOI 10.1266/ggs.80.213.

Peer) reviewing PDF | (2019:04:37083:2:0:NEW 18 Jul 2019) 
473

474

475

476

477

478

479

480

481

482

483

484

485

486

487

488

489

490

491

492

493

494

495

496

497

498

499

500

501

502

503

504

505

506

507

508

509

510

511

512

513

Scott E. 2005. A phylogeny of ranid frogs (Anura : Ranoidea : Ranidae), based on a simultaneous analysis of morphological and molecular data. Cladistics 21(6):507-574. DOI 10.1111/j.1096-0031.2005.00079.x.

Stamatakis A. 2006. RAxML-VI-HPC: maximum likelihood-based phylogenetic analyses with thousands of taxa and mixed models. Bioinformatics 22(21):2688-2690. DOI 10.1093/bioinformatics/btl446.

Stecher G, Kumar S, and Tamura K. 2016. MEGA7: Molecular Evolutionary Genetics Analysis Version 7.0 for Bigger Datasets. Molecular Biology and Evolution 33(7):1870-1874. DOI 10.1093/molbev/msw054.

van der Meijden A, Crottini A, Tarrant J, Turner A, and Vences M. 2011. Multi-locus phylogeny and evolution of reproductive modes in the Pyxicephalidae, an African endemic clade of frogs. African Journal of Herpetology 60(1):1-12. DOI 10.1080/21564574.2010.523904.

van der Meijden A, Vences M, Hoegg S, and Meyer A. 2005. A previously unrecognized radiation of ranid frogs in Southern Africa revealed by nuclear and mitochondrial DNA sequences. Molecular Phylogenetics and Evolution 37(3):674-685. DOI 10.1016/j.ympev.2005.05.001.

Wager VA. 1965. The frogs of South Africa. Purnell \& Sons (SA) Pty Ltd Cape Town.

Wang S, Liu L, Zhang M, and Jiang J. 2018. The complete mitochondrial genome of the Kaloula verrucosa (Anura: Microhylidae) and phylogenetic analyses. Mitochondrial DNA Part B 3(2):547-548. DOI 10.1080/23802359.2018.1467238.

Wiens JJ, Sukumaran J, Pyron RA, and Brown RM. 2009. Evolutionary and biogeographic origins of high tropical diversity in Old World frogs (Ranidae). Evolution 63(5):1217-1231. DOI 10.1111/j.15585646.2009.00610.x.

Xia Y, Zheng YC, Miura I, Wong PB, Murphy RW, and Zeng X. 2014. The evolution of mitochondrial genomes in modern frogs (Neobatrachia): nonadaptive evolution of mitochondrial genome reorganization. BMC Genomics 15(1):691. DOI 10.1186/1471-2164-15-691.

Xiang T, Wang B, Liang X, Jiang J, Li C, and Xie F. 2013. Complete mitochondrial genome of Paramegophrys oshanensis (Amphibia, Anura, Megophryidae). Mitochondrial DNA 24(5):472-474. DOI 10.3109/19401736.2013.766183.

Yan L, Geng ZZ, Yan P, and Wu XB. 2016. The complete mitochondrial genome of Glandirana tientaiensis (Ranidae, Anura). Mitochondrial DNA Part A 27(2):1154-1155. DOI 10.3109/19401736.2014.936415.

Yang J, Yu J, Liu J, Zhou M, Li B, and Ouyang B. 2018. Three New Ranidae Mitogenomes and the Evolution of Mitochondrial Gene Rearrangements among Ranidae Species. Asian Herpetological Research 9(2):85-98. DOI 10.16373/j.cnki.ahr.170084.

Ye L, Zhu C, Yu D, Zhang Y, and Zhang J. 2016. The complete mitochondrial genome of Hyla annectans (Anura: Hylidae). Mitochondrial DNA Part A 27(3):1593-1594. DOI 10.3109/19401736.2014.958684.

Yu D, Zhang J, Li P, Zheng R, and Shao C. 2015. Do cryptic species exist in Hoplobatrachus rugulosus? An examination using four nuclear genes, the Cyt $b$ gene and the complete MT genome. PloS One 10(4):e0124825. DOI 10.1371/journal.pone.0124825.

Yu D, Zhang J, and Zheng R. 2012a. The complete mitochondrial genome of Babina adenopleura (Anura: Ranidae). Mitochondrial DNA 23(6):423-425. DOI 10.3109/19401736.2012.710214.

Yu DN, Zhang JY, Zheng RQ, and Shao C. 2012b. The complete mitochondrial genome of Hoplobatrachus rugulosus (Anura: Dicroglossidae). Mitochondrial DNA 23(5):336-337. DOI 10.3109/19401736.2012.690748.

Zhang C, Xia Y, and Zeng X. 2016. Characterization of the mitochondrial genome of Amolops tuberodepressus

Peer) reviewing PDF | (2019:04:37083:2:0:NEW 18 Jul 2019) 
514

515

516

517

518

519

520

521

522

523

524

525

526

527

528

529

530

531

532

533

534

535

536

537

538

539

540

541

542

543
(Anura: Ranidae). Mitochondrial DNA Part A 27(4):2893-2894. DOI 10.3109/19401736.2015.1060425.

Zhang D, Gao F, Li WX, Jakovlić I, Zou H, Zhang J, and Wang GT. 2018b. PhyloSuite: an integrated and scalable desktop platform for streamlined molecular sequence data management and evolutionary phylogenetics studies. bioRxiv 489088 DOI 10.1101/489088.

Zhang JY, Luu BE, Yu DN, Zhang LP, Al-attar R, and Storey KB. 2019. The complete mitochondrial genome of Dryophytes versicolor: Phylogenetic relationship among Hylidae and mitochondrial protein-coding gene expression in response to freezing and anoxia. International Journal of Biological Macromolecules. 132(1):461-469 DOI 10.1016/j.ijbiomac.2019.1003.1220.

Zhang JY, Zhang LP, Yu DN, Storey KB, and Zheng RQ. 2018a. Complete mitochondrial genomes of Nanorana taihangnica and N. yunnanensis (Anura: Dicroglossidae) with novel gene arrangements and phylogenetic relationship of Dicroglossidae. BMC Evolutionary Biology 18(1):26. DOI 10.1186/s12862-018-1140-2.

Zhang JF, Nie LW, Wang Y, and Hu LL. 2009. The complete mitochondrial genome of the large-headed frog, Limnonectes bannaensis (Amphibia: Anura), and a novel gene organization in the vertebrate mtDNA. Gene 442(1-2):119-127. DOI 10.1016/j.gene.2009.04.018.

Zhang JY, Zhou CF, Gai YH, Song DX, and Zhou KY. 2008. The complete mitochondrial genome of Parafronurus youi (Insecta: Ephemeroptera) and phylogenetic position of the Ephemeroptera. Gene 424(1-2):18-24. DOI 10.1016/j.gene.2008.07.037.

Zhang P, Liang D, Mao RL, Hillis DM, Wake DB, and Cannatella DC. 2013. Efficient sequencing of Anuran mtDNAs and a mitogenomic exploration of the phylogeny and evolution of frogs. Molecular Biology and Evolution 30(8):1899-1915. DOI 10.1093/molbev/mst091.

Zhang P, Zhou H, Liang D, Liu YF, Chen YQ, and Qu LH. 2005. The complete mitochondrial genome of a tree frog, Polypedates megacephalus (Amphibia : Anura : Rhacophoridae), and a novel gene organization in living amphibians. Gene 346(14):133-143. DOI 10.1016/j.gene.2004.10.012.

Zhao Y, Meng H, and Su L. 2018. The complete mitochondrial genome of the mixtured pygmy frog Microhyla mixtura (Anura, Microhylidae). Conservation Genetics Resources 10(4):427-430. DOI 10.1007/s12686017-0841-y.

Zhou Y, Zhang JY, Zheng RQ, Yu BG, and Yang G. 2009. Complete nucleotide sequence and gene organization of the mitochondrial genome of Paa spinosa (Anura: Ranoidae). Gene 447(2):86-96. DOI 10.1016/j.gene.2009.07.009. 


\section{Ethics Approval and Consent to Participate}

546 P. adspersus frogs were purchased from a pet market; this species is permitted for scientific research in China.

\section{Competing interests}

548 The authors declare that they have no competing interests.

549 Acknowledgments

550 We are grateful to Le-Ping Zhang for her help in the study.

\section{Funding}

552 This research was supported by the Natural Science Foundation of Zhejiang Province (LQ16C030001), and the 553 National Natural Science Foundation of China (Nos. 31801963) for the study design, data collection and 554 analyses.

\section{Author Contributions}

556 Conceived and designed the experiments: YYC SQS DNY JYZ. Performed the experiments: YYC SQS LXL 557 ZJY DNY. Analyzed the data: YYC DNY. Contributed reagents/materials/analysis tools: JYZ DNY. Wrote the 558 paper: YYC SQS LXL KBS DNY JYZ. All the authors read and approved the final version of the manuscript.

\section{ORCID}

560 Jia-Yong Zhang http://orcid.org/0000-0002-7679-2548

561 Dan-Na Yu http://orcid.org/0000-0002-9870-1926

562 Kenneth B. Storey http://orcid.org/000-0002-7363-1853 


\section{Table legends}

565 Table 1. The partition schemes and best-fitting models selected of 10 protein-coding genes in the $10 \mathrm{mt}$ 566 PCGs dataset.

567 Table 2. Location of features in the mitogenome of $P$. adspersus.

568 Table 3. The comparability between non-coding region (NCR) and the deleted corresponding genes.

569 Table 4. Base composition of $P$. adspersus mitogenome. 


\section{Figure 1}

Figure 1. Graphical map of the mitogenome of $P$. adspersus .

Figure 1. Graphical map of the mitogenome of $\boldsymbol{P}$. adspersus . The tRNAs are labeled according to the three-letter amino acid codes. A gene name outside the circle indicates that the direction of transcription is anti clockwise, whereas a gene name inside the circle indicates that the direction of transcription is clockwise. 


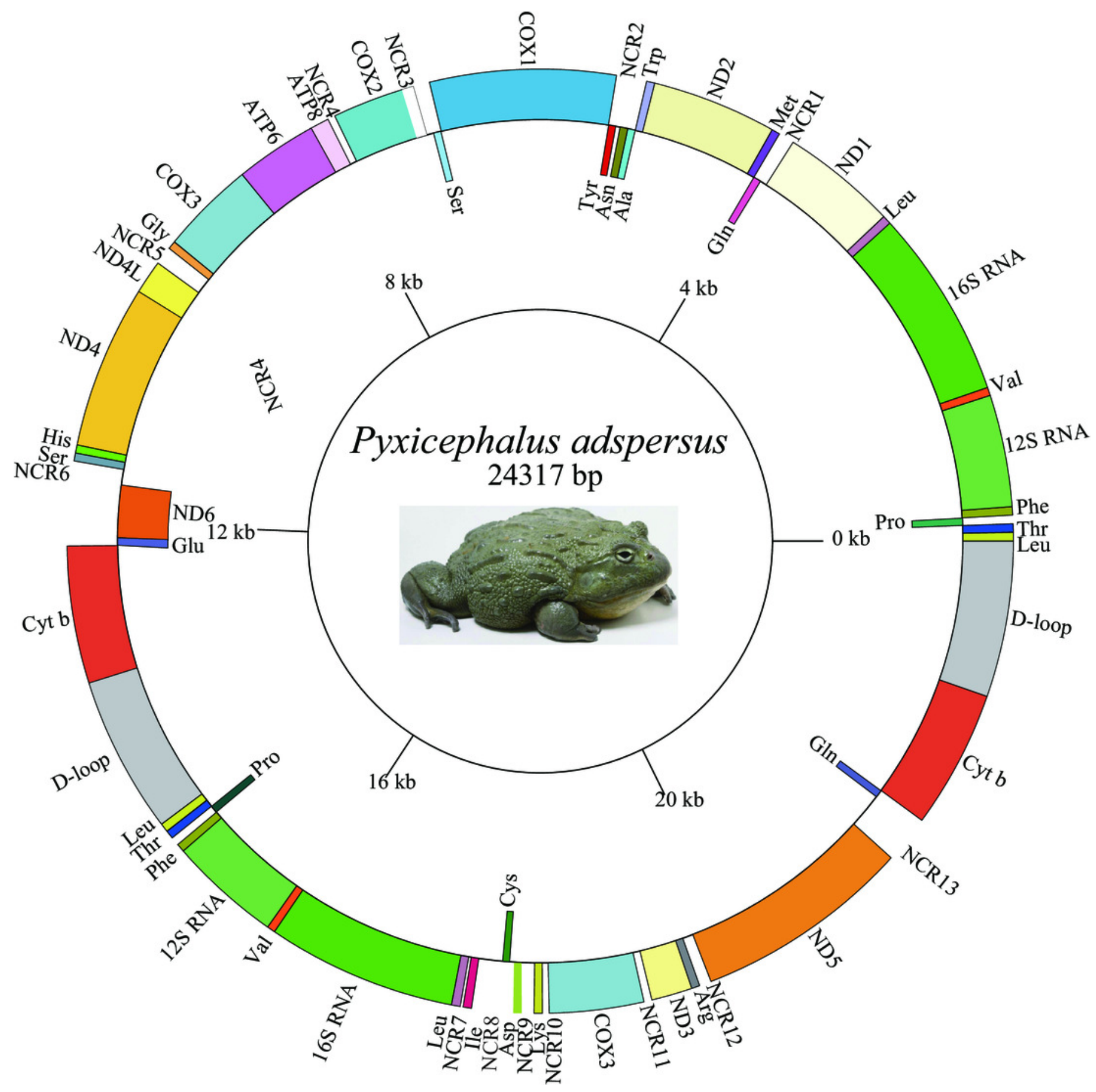


Figure 2

Figure 2 . The relative synonymous codon usage (RSCU) in the $P$. adspersus mitogenome.

Figure 2. The relative synonymous codon usage (RSCU) in the $P$, adspersus mitogenome. Codon families are provided on the $x$-axis along with the different combinations of synonymous codons that code for the same amino acid. RSCU are provided on the y-axis.

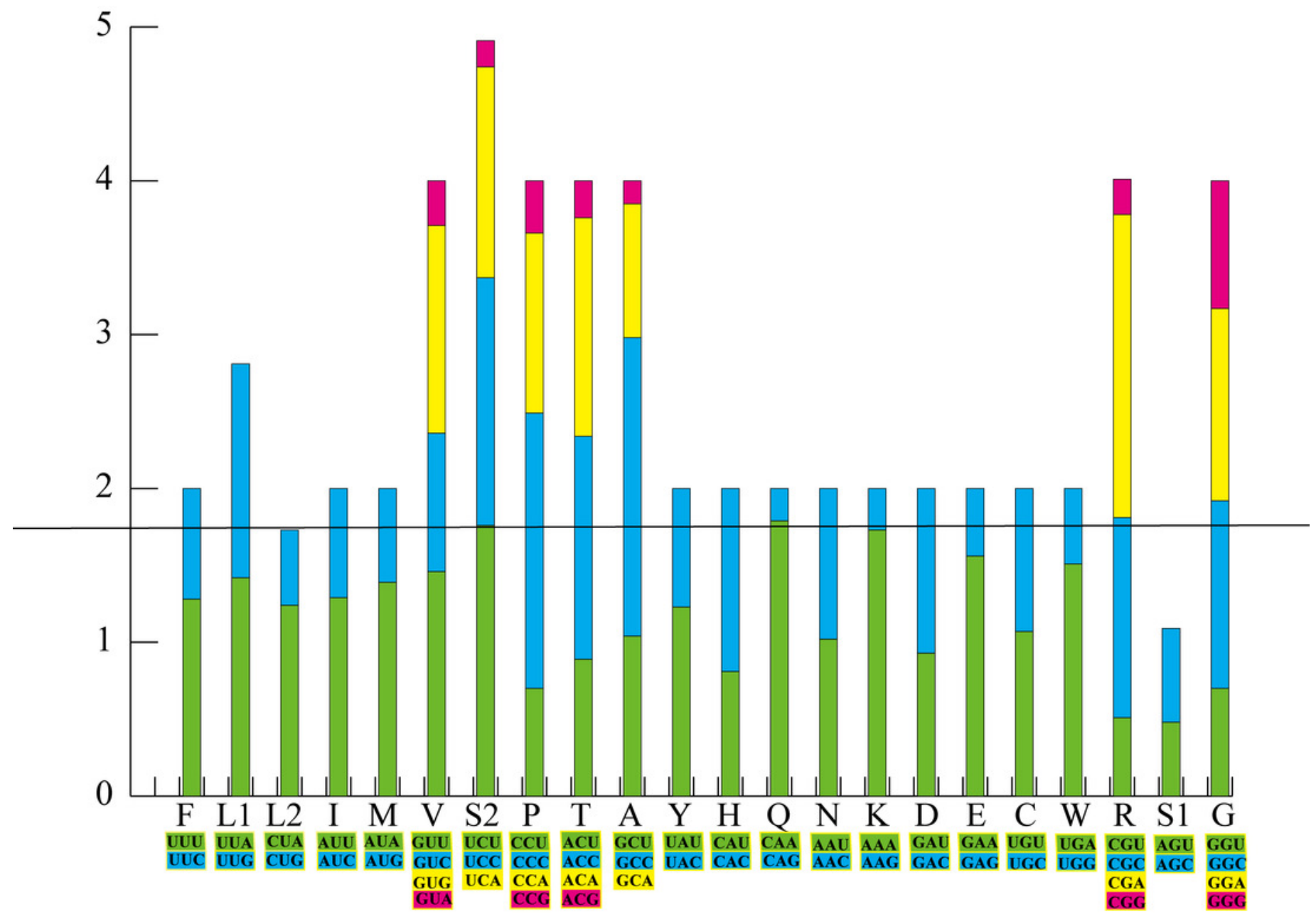




\section{Figure 3}

Figure 3. Proposed mechanism of gene rearrangements in the $P$. adspersus mitogenome under the Dimer-Mitogenome and a model of tandem duplication of gene regions.

Figure 3. Proposed mechanism of gene rearrangements in the $P$. adspersus mitogenome under the Dimer-Mitogenome and a model of tandem duplication of gene regions. (A) Typical Dicroglossidae gene order. (B) The dimeric molecule with two monomers linked head-to-tail and subsequent first deletions of partial genes or complete genes resulting in the derived gene order. (C) State in $P$. adspersus after the final duplication and deletion.

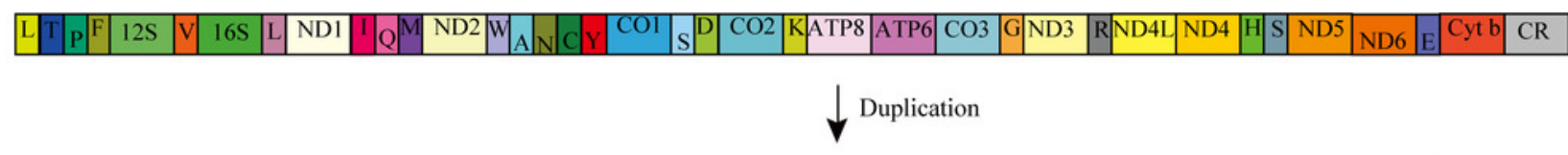

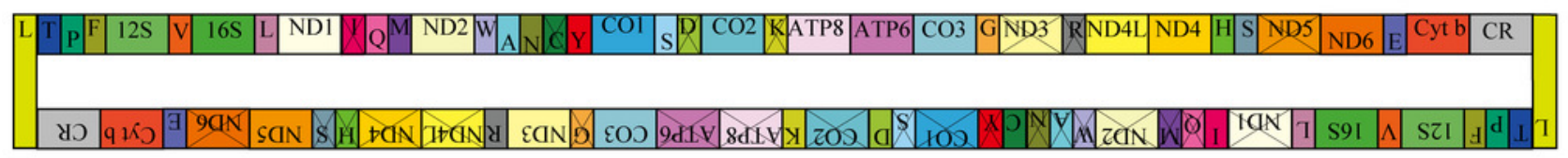

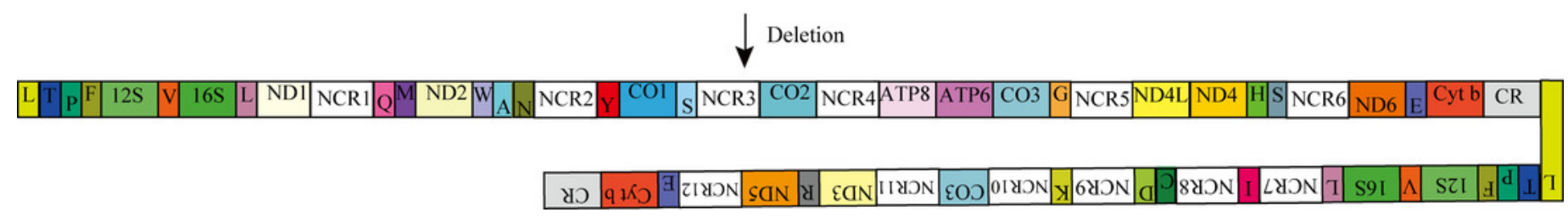




\section{Figure 4}

Figure 4. Phylogenetic relationships of Ceratobatrachidae, Dicroglossidae, Mantellidae, Petropedetidae, Phrynobatrachidae, Pyxicephalidae, Ptychadenidae, Ranidae, and Rhacophoridae based on 10 protein-coding genes using nucleotide datasets.

Figure 4. Phylogenetic relationships of Ceratobatrachidae, Dicroglossidae, Mantellidae, Petropedetidae, Phrynobatrachidae, Pyxicephalidae, Ptychadenidae, Ranidae, and Rhacophoridae based on $\mathbf{1 0}$ protein-coding genes using nucleotide datasets. Phylogenetic analyses using nucleotide datasets were carried out for 59 frog species based on all 10 protein-coding genes from their respective $\mathrm{mt}$ genomes. Branch lengths and topology are from $\mathrm{Bl}$ analysis. The tree was rooted with four out-groups (Micryletta inornata, M. mixtura, Glyphoglossus yunnanensis and Kaloula verrucosa). Numbers above the nodes are the posterior probabilities of BI on the left and the bootstrap values of $M L$ on the right. 


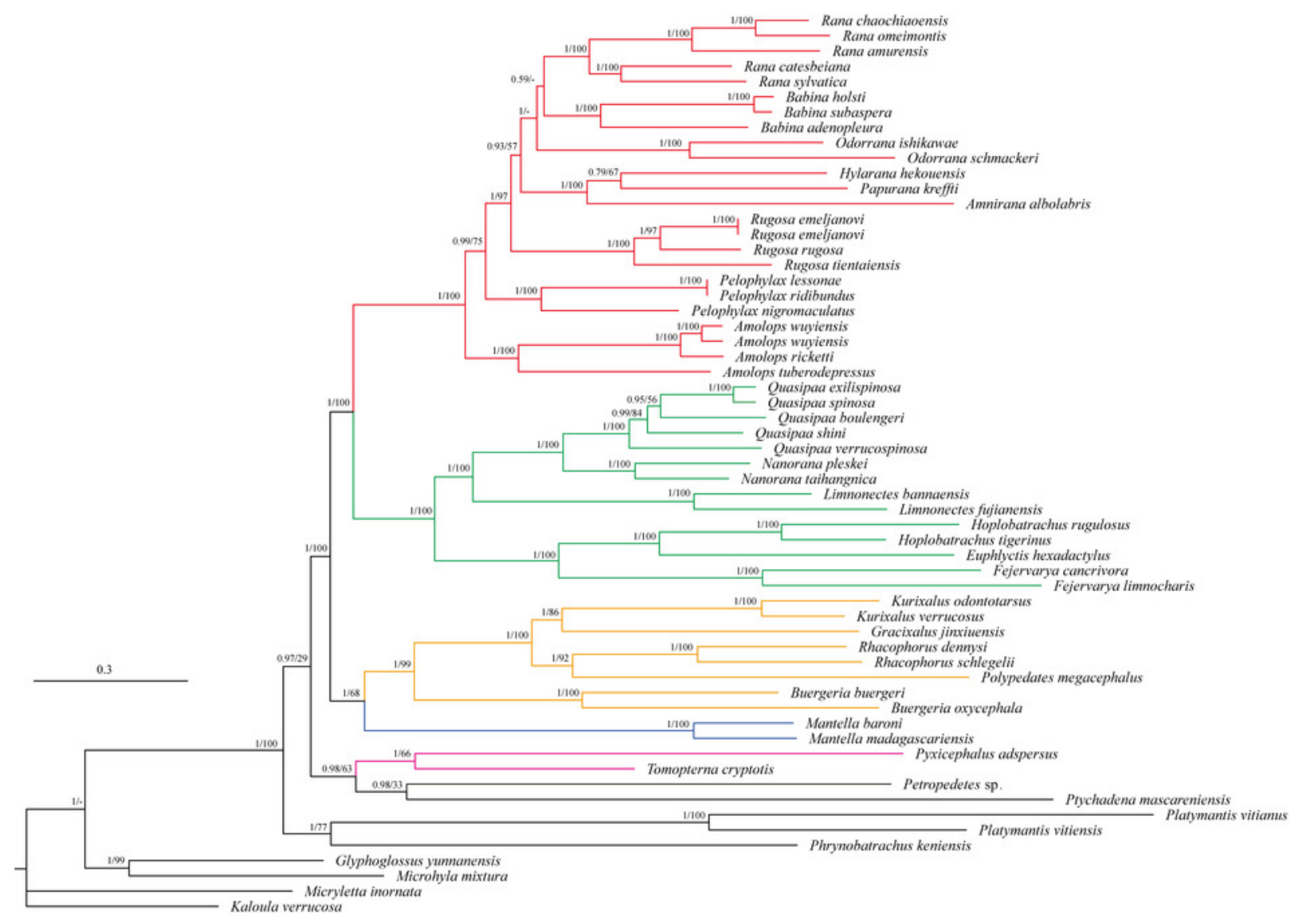

Mantellidae | Pyxicephalidae | Petropedetidae

|Ceratobatrachidae I Phrynobatrachidae

outgroups 


\section{Table $\mathbf{1}$ (on next page)}

Table 1. The partition schemes and best-fitting mod els selected of 10 protein-coding genes in the PCG123 data.

Table 1. The partition schemes and best-fitting mod els selected of 10 protein-coding genes in the PCG123 data. 
1 Table 1. The partition schemes and best-fitting models selected of 10 protein-coding genes in PCG123 data

\begin{tabular}{|c|c|c|}
\hline \multicolumn{3}{|c|}{ Nucleotide sequence alignments } \\
\hline Subset & Subset Partitions & Best Model \\
\hline Partition 1 & atp6_pos1, cox3_pos3, nd1_pos1, nd2_pos1, nd3_pos1, nd4_pos1 & $\mathrm{GTR}+\mathrm{I}+\mathrm{G}$ \\
\hline Partition 2 & atp6_pos2, cox2_pos2, nd2_pos2, nd3_pos2, nd4_pos2, nd41_pos2 & $\mathrm{TVM}+\mathrm{I}+\mathrm{G}$ \\
\hline Partition 3 & atp6_pos3, nd1_pos3, nd2_pos3, nd3_pos3, nd4_pos3, nd41_pos3 & $\operatorname{TrN}+\mathrm{G}$ \\
\hline Partition 4 & cox1_pos1, cox3_pos1 & $\mathrm{SYM}+\mathrm{I}+\mathrm{G}$ \\
\hline Partition 5 & cox1_pos2, cytb_pos2, nd1_pos2 & $\mathrm{TIM}+\mathrm{I}+\mathrm{G}$ \\
\hline Partition 6 & cox1_pos3 & $\operatorname{TrN}+\mathrm{G}$ \\
\hline Partition 7 & cox2_pos1, cytb_pos1, nd41_pos1 & $\mathrm{SYM}+\mathrm{I}+\mathrm{G}$ \\
\hline Partition 8 & $\operatorname{cox} 2 \_$pos 3 & $\operatorname{TrN}+\mathrm{G}$ \\
\hline Partition 9 & $\operatorname{cox} 3 \_$pos 2 & $\mathrm{JC}$ \\
\hline Partition 10 & cytb_pos3 & $\operatorname{TrN}+\mathrm{I}+\mathrm{G}$ \\
\hline
\end{tabular}




\section{Table 2 (on next page)}

Table 2. Location of features in the mitogenome of $P$. adspersus .

Table 2. Location of features in the mitogenome of $P$. adspersus . 
Table 2

\begin{tabular}{|c|c|c|c|c|c|c|}
\hline Gene/region & $\begin{array}{c}\text { Start } \\
\text { position }\end{array}$ & $\begin{array}{c}\text { Spacer } \\
(+) \\
\text { overlap (- } \\
\text { ( }\end{array}$ & $\begin{array}{l}\text { Length } \\
\quad \text { (bp } \\
\text { ) }\end{array}$ & $\begin{array}{l}\text { Start } \\
\text { codon }\end{array}$ & $\begin{array}{l}\text { Stop } \\
\text { codon }\end{array}$ & strand \\
\hline$t R N A^{\text {Leu }}$ & $1-72$ & +1 & 72 & & & $\mathrm{H}$ \\
\hline$t R N A^{T h r}$ & $74-143$ & 0 & 70 & & & $\mathrm{H}$ \\
\hline$t R N A^{\text {Pro }}$ & $144-212$ & +1 & 69 & & & $\mathrm{~L}$ \\
\hline$t R N A^{P h e}$ & $214-283$ & 0 & 70 & & & $\mathrm{H}$ \\
\hline $12 S r R N A$ & $284-1215$ & 0 & 932 & & & $\mathrm{H}$ \\
\hline$t R N A^{\text {Val }}$ & $1216-1283$ & 0 & 68 & & & $\mathrm{H}$ \\
\hline $16 S r R N A$ & $1284-2861$ & 0 & 1578 & & & $\mathrm{H}$ \\
\hline$t R N A^{\operatorname{Leu}(U U R)}$ & $2862-2934$ & 0 & 73 & & & $\mathrm{H}$ \\
\hline ND1 & $2935-3897$ & +60 & 963 & ATG & TAG & $\mathrm{H}$ \\
\hline NCR1 & $3898-3957$ & & 60 & & & \\
\hline$t R N A^{G l n}$ & $3958-4028$ & -1 & 71 & & & $\mathrm{~L}$ \\
\hline$t R N A^{M e t}$ & $4028-4096$ & 0 & 69 & & & $\mathrm{H}$ \\
\hline ND2 & $4097-5134$ & -2 & 1038 & ATT & TAG & $\mathrm{H}$ \\
\hline$t R N A^{\operatorname{Tr} p}$ & $5133-5201$ & 0 & 69 & & & $\mathrm{H}$ \\
\hline$t R N A^{A l a}$ & $5202-5271$ & 0 & 70 & & & $\mathrm{~L}$ \\
\hline$t R N A^{A s n}$ & $5272-5344$ & +39 & 73 & & & $\mathrm{~L}$ \\
\hline NCR2 & $5345-5383$ & & 39 & & & \\
\hline$t R N A^{T y r}$ & $5384-5450$ & +1 & 67 & & & $\mathrm{~L}$ \\
\hline COX1 & $5452-6994$ & +2 & 1543 & GTG & $\mathrm{T}$ & $\mathrm{H}$ \\
\hline$t R N A^{\operatorname{Ser}(U C N)}$ & $6997-7067$ & +69 & 71 & & & $\mathrm{~L}$ \\
\hline NCR3 & $7067-7130$ & & 59 & & & \\
\hline COX2 & $7131-7818$ & +61 & 688 & ATG & $\mathrm{T}$ & $\mathrm{H}$ \\
\hline NCR4 & $7817-7879$ & & 61 & & & \\
\hline ATP & $7880-8044$ & -10 & 165 & ATG & TAA & $\mathrm{H}$ \\
\hline ATP6 & $8035-8716$ & 0 & 682 & ATG & $\mathrm{T}$ & $\mathrm{H}$ \\
\hline COX3 & $8717-9500$ & +1 & 784 & ATG & $\mathrm{T}$ & $\mathrm{H}$ \\
\hline$t R N A^{G l y}$ & $9501-9569$ & +150 & 69 & & & $\mathrm{H}$ \\
\hline NCR5 & $9570-9719$ & & 150 & & & \\
\hline$N D 4 L$ & $9720-10007$ & -7 & 288 & ATG & TAA & $\mathrm{H}$ \\
\hline ND4 & $10001-11363$ & 0 & 1363 & ATG & $\mathrm{T}$ & $\mathrm{H}$ \\
\hline$t R N A^{H i s}$ & $11364-11430$ & 0 & 67 & & & $\mathrm{H}$ \\
\hline$t R N A^{\operatorname{Ser}(A G Y)}$ & $11431-11497$ & +143 & 67 & & & $\mathrm{H}$ \\
\hline NCR6 & $11496-11640$ & & 143 & & & \\
\hline ND6 & $11641-12126$ & 0 & 486 & ATG & AGG & $\mathrm{L}$ \\
\hline$t R N A^{G l u}$ & $12127-12196$ & +1 & 70 & & & $\mathrm{~L}$ \\
\hline
\end{tabular}




\begin{tabular}{|c|c|c|c|c|c|c|}
\hline$C y t b$ & $12198-13349$ & 0 & 1152 & ATG & TAA & $\mathrm{H}$ \\
\hline CR1 & $13350-14646$ & 0 & 1297 & & & $\mathrm{H}$ \\
\hline$t R N A^{L e u}$ & $14647-14718$ & +1 & 72 & & & $\mathrm{H}$ \\
\hline$t R N A^{T h r}$ & $14720-14789$ & 0 & 70 & & & $\mathrm{H}$ \\
\hline$t R N A^{\text {Pro }}$ & $14790-14858$ & +1 & 69 & & & $\mathrm{~L}$ \\
\hline$t R N A^{\text {Phe }}$ & $14860-14929$ & 0 & 70 & & & $\mathrm{H}$ \\
\hline $12 S r R N A$ & $14930-15861$ & 0 & 932 & & & $\mathrm{H}$ \\
\hline$t R N A^{V a l}$ & $15862-15929$ & 0 & 68 & & & $\mathrm{H}$ \\
\hline $16 S r R N A$ & $15930-17507$ & 0 & 1578 & & & $\mathrm{H}$ \\
\hline$t R N A^{\operatorname{Leu}(U U R)}$ & $17508-17580$ & +22 & 73 & & & $\mathrm{H}$ \\
\hline NCR7 & $17579-17602$ & & 22 & & & \\
\hline$t R N A^{\text {Ile }}$ & $17603-17673$ & +219 & 71 & & & $\mathrm{H}$ \\
\hline NCR8 & $17672-17866$ & & 219 & & & \\
\hline $\mathrm{OL}$ & $17867-17895$ & & 29 & & & $\mathrm{~L}$ \\
\hline$t R N A^{C y s}$ & $17893-17957$ & +9 & 65 & & & $\mathrm{~L}$ \\
\hline$t R N A^{A s p}$ & $17967-18035$ & +151 & 69 & & & $\mathrm{H}$ \\
\hline NCR9 & $18034-18186$ & & 151 & & & \\
\hline$t R N A^{L y s}$ & $18187-18256$ & +54 & 70 & & & $\mathrm{H}$ \\
\hline NCR10 & $18255-18310$ & & 54 & & & \\
\hline COX3 & 18311-19094 & +65 & 784 & ATG & $\mathrm{T}$ & $\mathrm{H}$ \\
\hline NCR11 & 19093-19159 & & 65 & & & \\
\hline ND3 & $19160-19501$ & -2 & 342 & ATG & TAA & $\mathrm{H}$ \\
\hline$t R N A^{A r g}$ & $19500-19568$ & +98 & 69 & & & $\mathrm{H}$ \\
\hline NCR12 & 19569-19666 & & 98 & & & \\
\hline ND5 & -21472 & +324 & 1806 & ATG & AGG & $\mathrm{H}$ \\
\hline NCR13 & $21471-21796$ & & 324 & & & \\
\hline$t R N A^{G l u}$ & $21797-21867$ & +1 & 71 & & & $\mathrm{~L}$ \\
\hline$C Y T B$ & $21869-23020$ & 0 & 1152 & ATG & TAA & $\mathrm{H}$ \\
\hline$C R 2$ & $23021-24317$ & & 1297 & & & $\mathrm{H}$ \\
\hline
\end{tabular}




\section{Table 3 (on next page)}

Table 3. The comparability between non-coding region (NCR) and the deleted corresponding genes.

Table 3. The comparability between non-coding region (NCR) and the deleted corresponding genes. 
$1 \quad$ Table 3

\begin{tabular}{lll}
\hline Non-coding region & Corresponding genes & Comparability \\
\hline NCR1 & Ile & $50 \%$ \\
NCR2 & OL-tRNA $^{\text {Cys }}$ & $48.7 \%$ \\
NCR3 & Asp & $59.4 \%$ \\
NCR4 & Lys & $50.7 \%$ \\
NCR5 & ND3-tRNA Arg & $67.3 \%$ \\
NCR6 & ND5 & $60.1 \%$ \\
NCR7 & ND1 & $100 \%$ \\
NCR8 & Gln-Met-ND2-tRNA ${ }^{\text {Trp_ }}$ & $53.0 \%$ \\
& tRNA ${ }^{\text {Ala }-t R N A}{ }^{\text {Asn }}$ & \\
NCR9 & COX2 & $50.3 \%$ \\
NCR10 & ATP8-ATP6 & $57.4 \%$ \\
NCR11 & Gly & $73.9 \%$ \\
NCR12 & ND4-ND4L-tRNA ${ }^{\text {His_ }}$ & $48.4 \%$ \\
& tRNA & \\
NCR13 & ND6 & $92.6 \%$ \\
\hline
\end{tabular}

2 


\section{Table 4(on next page)}

Table 4. Base composition of $P$. adspersus mitogenome.

Table 4. Base composition of $P$. adspersus mitogenome. 
Table 4

\begin{tabular}{|c|c|c|c|c|c|c|c|c|}
\hline & $\mathrm{A} \%$ & $\mathrm{~T} \%$ & $\mathrm{G} \%$, & $\mathrm{C} \%$ & АT $\%$ & $\mathrm{GC} \%$ & $\begin{array}{l}\text { AT } \\
\text { Skewness }\end{array}$ & $\begin{array}{l}\text { GC } \\
\text { Skewness }\end{array}$ \\
\hline $\begin{array}{l}\text { Whole } \\
\text { genome }\end{array}$ & 29.5 & 28.2 & 14.5 & 27.8 & 57.7 & 42.3 & 0.022 & -0.314 \\
\hline $\begin{array}{l}\text { Protein- } \\
\text { coding } \\
\text { genes }\end{array}$ & 26.1 & 30.0 & 14.3 & 29.6 & 56.1 & 43.9 & -0.071 & -0.348 \\
\hline $\begin{array}{l}\text { 1st } \\
\text { codon } \\
\text { positions }\end{array}$ & 26.9 & 28.1 & 18 & 27.1 & 55 & 45.1 & -0.022 & -0.202 \\
\hline $\begin{array}{l}\text { 2nd } \\
\text { codon } \\
\text { positions }\end{array}$ & 23.5 & 33.5 & 13.1 & 29.9 & 57 & 43 & -0.175 & -0.392 \\
\hline $\begin{array}{l}3 \mathrm{rd} \\
\text { codon } \\
\text { positions }\end{array}$ & 27.9 & 28.5 & 11.9 & 31.7 & 56.4 & 43.6 & -0.012 & -0.455 \\
\hline $\begin{array}{l}\text { tRNA } \\
\text { genes }\end{array}$ & 28.8 & 27.8 & 22.1 & 21.2 & 56.6 & 43.3 & 0.018 & 0.021 \\
\hline $\begin{array}{l}\text { rRNA } \\
\text { genes }\end{array}$ & 33.3 & 24.5 & 18.2 & 24.0 & 57.8 & 42.2 & 0.151 & -0.139 \\
\hline $\begin{array}{l}\text { Control } \\
\text { region }\end{array}$ & 31.9 & 33.6 & 12.5 & 22.0 & 65.5 & 34.5 & -0.026 & -0.275 \\
\hline
\end{tabular}

